\title{
Blind nasotracheal intubation is facilitated by neutral head position and endotracheal tube cuff inflation in spontaneously breathing patients
}

\author{
[L'intubation nasotrachéale à l'aveugle est facilitée par la position neutre de la tête et le \\ gonflement du ballonnet de la sonde endotrachéale chez des patients en ventilation spontanée]
}

Yung-Tai Chung MD MSc, Maw-Sheng Sun MD, Hung-Shan Wu MD

Purpose: To evaluate, using an endotracheal tube mounted on a flexible lighted stylet, how the patient's head-neck position and inflation of the endotracheal cuff affect correct alignment of the tube tip with the glottis.

Methods: Eighty-two patients were enrolled. The course of the endotracheal tube in the pharynx was examined by observing the anterior neck for transillumination in each patient under four different intubating conditions. These were: patient's head on pad $(8 \mathrm{~cm})$ with the cuff deflated (HP-deflation group); patient's head on pad with the cuff inflated (HP-inflation group); patient's head on bed with the cuff deflated (HB-deflation group); and patient's head on bed with the cuff inflated (HB-inflation group).

Results: Both a head on bed (neutral) position or endotracheal tube cuff inflation ( $15 \mathrm{~mL}$ of air) significantly increased the frequency of correct alignment of the tip of the endotracheal tube with the glottis. Blind nasotracheal intubation (BNTI) was successful in 69 patients (84\%). Lightwand-assisted nasotracheal intubation was required in II of the remaining 13 patients (13\%) and fibreoptic bronchoscopyassisted intubation was performed in the last two patients.

Conclusion: A neutral position of the head combined with endotracheal tube cuff inflation is recommended for BNTI.

Objectif : Évaluer, au moyen d'une sonde endotrachéale montée sur un stylet lumineux flexible, l'effet de la position neutre de la tête du patient et du gonflement du ballonnet endotrachéal sur l'alignement correct de la pointe de la sonde avec la glotte.

Méthode : Quatre-vingt-deux patients ont participé à l'étude. La poussée de la sonde endotrachéale dans le pharynx a été suivie en vérifiant la présence de transillumination à la partie antérieure du cou chez chaque patient, selon quatre conditions d'intubation : tête sur un coussin $(8 \mathrm{~cm})$ et ballonnet dégonflé (groupe TC-dégonflement) ; tête sur un coussin et ballonnet gonflé (groupe TC-gonflement) ; tête sur le lit et ballonnet dégonflé (groupe TL-dégonflement) et tête sur le lit et ballonnet gonflé (groupe TL-gonflement).

Résultats : La position neutre de la tête sur le lit et le gonflement du ballonnet endotrachéal, avec $15 \mathrm{~mL}$ d'air, ont fait augmenter significativement la fréquence de l'alignement correct de la pointe de la sonde endotrachéale avec la glotte. L'intubation nasotrachéale à l'aveugle (INTA) a été réussie chez 69 patients (84\%). L'intubation nasotrachéale assistée avec le stylet lumineux a été nécessaire chez II des 13 patients restants (13\%) et l'intubation assistée par fibroscopie bronchique a été réalisée chez les deux derniers patients.

Conclusion : Une position neutre de la tête, combinée au gonflement du ballonnet de la sonde endotrachéale, est recommandée pour I'INTA.

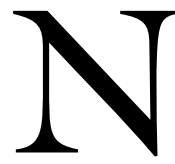

OWADAYS fibreoptic bronchoscopyassisted intubation is the first choice when orotracheal intubation is difficult or impossible. Blind nasotracheal intubation (BNTI) has been long recognized as relatively easy in spontaneously breathing patients ${ }^{1}$ and success rates from $72 \%$ to $86 \%$ have been reported. ${ }^{2-5}$ However, BNTI has almost been forgotten. We assumed that if BNTI was understood better and mastered easily, it would regain acceptability.

When a lighted stylet is introduced into the endotracheal tube, the endotracheal tube can be guided into the trachea by transillumination of the soft tissues of the anterior neck. ${ }^{6}$ We propose a prospective, open and comparative study to evaluate, using a flexible lighted stylet, (Trachlight ${ }^{\mathrm{TM}}$ Laerdal Medical Corp.,

From the Department of Anesthesiology, Changhua Christian Hospital, Changhua, Taiwan.

Address correspondence to: Dr. Yung-Tai Chung, Department of Anesthesiology, Changhua Christian Hospital, 135 Nanhsiao Street,

Changhua, 500, Taiwan, R.O.C. Phone: 88-64-7238595, ext. 5311, or 5312; Fax: 88-64-7232942; E-mail: 73260@cch.org.tw Accepted for publication July 15, 2002.

Accepted for publication February 12, 2003. 


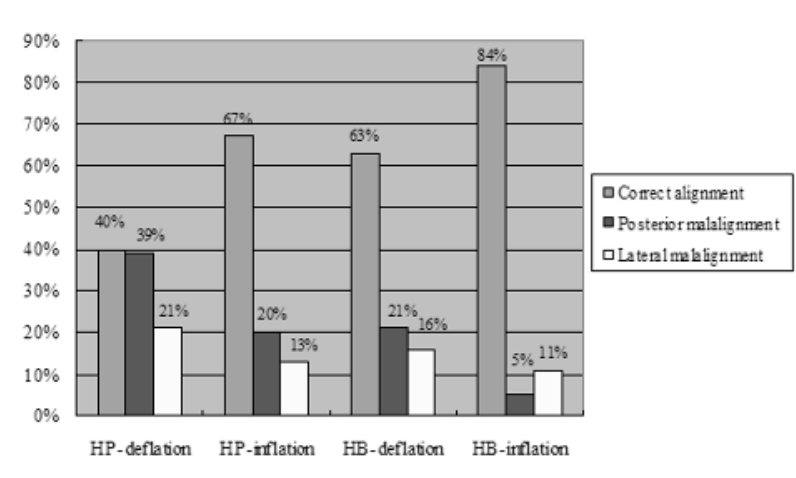

FIGURE Alignment of the tip of the endotracheal tube with the glottic opening under four intubating conditions.
TABLE I Patient characteristics

Number of patient studied

82

Age (yr; mean \pm SD)

Male/female

Body weight $(\mathrm{kg})$

ASA class II/III

$46.6 \pm 17.1$

$69 / 13$

$64.8 \pm 11.5$

$48 / 34$

TABLE II Classification of the alignment of the tip of the endotracheal tube with the glottic opening

\begin{tabular}{ll}
\hline Correct alignment & $\begin{array}{l}\text { A well-defined bright glow on the } \\
\text { cricothyroid membrane. }\end{array}$ \\
Anterior malalignment & $\begin{array}{l}\text { A bright glow above the level of thyroid } \\
\text { cartilage. }\end{array}$ \\
Lateral malalignment & $\begin{array}{l}\text { A glow in the superior lateral aspect of } \\
\text { the neck. }\end{array}$ \\
Posterior malalignment & Dull or absent illumination.
\end{tabular}

Armonk, NY, USA), the influence of patient's headneck position and endotracheal tube cuff inflation on the success rate of BNTI.

\section{Materials and methods}

The study was approved by the Institutional Review Board of the hospital, and a written informed consent was obtained from each patient. Eighty-two patients who needed nasotracheal intubations were included (Table I). All patients underwent oral or maxillo-facial surgeries, and half had a limited mouth opening (inter-incisor distance of $20 \mathrm{~mm}$ or less). Patients were excluded if they had a coagulopathy, cervical instability, basal skull fracture, nasal bone fracture, nasal obstruction, upper airway foreign body, tumour, polyp, or laryngeal injury.

The patients were awake during the study and intubation. Standard monitors were applied. All patients received $2 \mu \mathrm{g} \cdot \mathrm{kg}^{-1}$ of fentanyl and $0.2 \mathrm{mg}$ of glycopyrrolate intravenously, and the upper airway was anesthetized with a local anesthetic. Portex ${ }^{\mathrm{TM}}$ (Sims Portex Ltd., Kent, UK) ivory nasal endotracheal tubes were employed for intubation. The internal stiff wire of the Trachlight $^{\mathrm{TM}}$ stylet was removed. Five minutes after topical anesthesia, with the patient in a supine position, the tube-lightwand combination was inserted through the nostril and advanced until there was a loss of resistance, indicating that the tip of the tube entered the oropharynx. The operating room lights were dimmed and the lightwand was switched on.

We examined the endotracheal tube moving towards the glottis by observing the anterior neck for transillumination in each patient under four different intubating conditions. These were: patient's head on pad $(8 \mathrm{~cm}$ high) combined with cuff deflation (HP-deflation group); patient's head on pad combined with the cuff inflation ( $15 \mathrm{~mL}$ of air $)^{7}$ (HP-inflation group); patient's head on bed (neutral position) combined with cuff deflation (HB-deflation group); and patient's head on bed combined with cuff inflation (HB-inflation group). All examinations were performed in the above order. Under each condition, the endotracheal tube was advanced gently during inspiration, without rotating the tube. The tip of the endotracheal tube was withdrawn back to the oropharynx after each examination. Alignment of the endotracheal tube with the glottis was classified according to transillumination at the anterior neck ${ }^{8}$ (Table II). After the examinations, actual BNTI was attempted. The Trachlight ${ }^{\mathrm{TM}}$ or, subsequently, a fibreoptic bronchoscope was used when BNTI failed and for patients who had no correct alignment under any condition.

Logistic regression was used to evaluate the effects of the endotracheal cuff and head position on the success rate of BNTI. The effect of the endotracheal cuff $\left(\mathrm{x}_{1}\right)$ or head position $\left(\mathrm{x}_{2}\right)$ were dichotomous variables. For $\mathrm{x}_{1}$, one represented cuff inflation and zero cuff deflation; for $\mathrm{x}_{2}$, one represented head on bed and zero head on pad. A $P$ value less than 0.05 was considered statistically significant.

\section{Results}

The frequency of correct alignment was $40 \%(33 / 82)$ in the HP-deflation group, $67 \%(55 / 82)$ in the HPinflation group, $63 \%(52 / 82)$ in the HB-deflation group, and $84 \%(69 / 82)$ in the HB-inflation group (Figure). There was no anterior malalignment in all groups. Both head on bed and endotracheal tube cuff inflation significantly increased the frequency of correct alignment (Table III). 
TABLE III Effect of head position or the endotracheal tube cuff inflation on correct alignment

\begin{tabular}{|c|c|c|c|c|c|}
\hline & & S.E. & P value & Odds ratio & 95\% CI for odds ratio \\
\hline Constant $(\alpha)$ & -0.398 & & & & \\
\hline Cuff effect $\left(\beta_{1}\right)$ & 1.112 & 0.247 & 0.000 & 3.040 & $1.847-4.934$ \\
\hline Head position effect $\left(B_{2}\right)$ & 0.950 & 0.246 & 0.000 & 2.587 & $1.597-4.191$ \\
\hline
\end{tabular}

S.E. = standard error; $\mathrm{CI}=$ confidence interval.

BNTI was successful in all the 69 patients $(84 \%)$ who had a correct alignment under at least one intubating condition; Trachlight ${ }^{\mathrm{TM}}$-assisted nasotracheal intubation was performed in 11 patients (13\%); fibreoptic bronchoscopy-assisted intubation was performed in two patients in whom a glottic narrowing had not been recognized before the study.

Movement of the endotracheal tube in the pharynx induced grimacing in 13 patients (16\%) and insertion of the tube into the trachea caused mild cough in 19 patients $(23 \%)$. Mild nasal bleeding was noted in 14 patients (17\%).

\section{Discussion}

BNTI can be facilitated by elevating the tip of the endotracheal tube. This can be achieved by inflating the endotracheal tube cuff, ${ }^{7}$ or using a directional-tip endotracheal tube, Endotrolol ${ }^{\mathrm{TM}}$ tube $^{3,5}$ (Mallinckrodt, Athlone, Ireland) or a modified Trachlight ${ }^{\mathrm{TM}} .{ }^{9}$ In addition to endotracheal cuff inflation, ease of intubation is further augmented by placing the patient's head in a neutral position.

The sniffing position has been long acknowledged as the optimum head position for BNTI for decades. ${ }^{1}$ However, the sniffing position is contraindicated in patients with cervical instability. A neutral head position combined with cuff inflation will result in comparable success rates $(84 \%)$.

Lightwand-assisted nasotracheal intubation has been reported to be highly successful $(92.6$ and $98.4 \%){ }^{10}$ The success rate of this technique would have reached $98 \%(80 / 82)$ in our study, had the technique been adopted initially in all cases. A lighted stylet can reduce malposition, lateral or posterior, of the endotracheal tube which will be guided by transillumination at the anterior neck.

Half of the patients included in the study had limited mouth opening and, for safety reasons, we decided to proceed with patients breathing spontaneously after adequate local anesthesia of the upper airway.

The study was neither controlled nor randomized, so systemic errors, related to the operator, the patients or the study sequence might be involved. On the other hand, obtaining four measurements on a single subject will reduce inter-individual variations.

In summary, in spontaneously breathing patients, a neutral position of the head combined with endotracheal tube cuff inflation is recommended for BNTI.

\section{References}

1 Magill IW, Macintosh RR, Hewer CL, Nosworthy MD, Mc Connell WS. Lest we forget. Anaesthesia 1975; 30: 476-90.

2 O'Brian DJ, Danzl DF, Hooker EA, Daniel LM, Dolan $M C$. Prehospital blind nasotracheal intubation by paramedics. Ann Emerg Med 1989; 18: 612-7.

3 Hooker EA, Hagen S, Coleman R, Heine MF, Greenwood P. Directional-tip endotracheal tubes for blind nasotracheal intubation. Acad Emerg Med 1996; 3: 586-9.

4 Roppolo LP, Vilke GM, Chan TC, Krishel S, Haydon SR, Rosen $P$. Nasotracheal intubation in the emergency department, revisited. J Emerg Med 1999; 17: 791-9.

$5 O^{\prime}$ Connor RE, Megargel RE, Schnyder ME, Madden JF, Bitner $M$, Ross $R$. Paramedic success rate for blind nasotracheal intubation is improved with the use of an endotracheal tube with directional tip control. Ann Emerg Med 2000; 36: 328-32.

6 Hung OR, Pytka S, Morris I, et al. Clinical trial of a new lightwand device (Trachlight) to intubate the trachea. Anesthesiology 1995; 83: 509-14.

7 Van Elstraete AC, Pennant JH, Gajraj NM, Victory $R A$. Tracheal tube cuff inflation as an aid to blind nasotracheal intubation. Br J Anaesth 1993; 70: 691-3.

8 Agro F, Hung OR, Cataldo R, Carassiti M, Gherardi S. Lightwand intubation using the Trachlight ${ }^{\mathrm{TM}}$ : a brief review of current knowledge. Can J Anesth 2001; 48: 592-9.

9 Iseki K, Murakawa M, Tase C, Otsuki M. Use of a modified lightwand for nasal intubation (Letter). Anesthesiology 1999; 90: 635.

10 Favaro R, Tordiglione P, Di Lascio F, et al. Effective nasotracheal intubation using a modified transillumination technique. Can J Anesth 2002; 49: 91-5. 